\title{
PHILOSOPHY
}

\section{AESTHETIC IDEAS IN UKRAINIAN AND BRITISH PHILOSOPHY OF 17-18TH CENTURIES}

\author{
PhD student Viktoriya Havrylenko \\ Ukraine, Sumy, Sumy State University; \\ Department of Philosophy of the Sumy State University
}

DOI: https://doi.org/10.31435/rsglobal_ijitss/31012020/6873

\section{ARTICLE INFO}

Received 20 November 2019

Accepted 15 January 2020

Published 31 January 2020

\section{KEYWORDS}

beauty,

ugliness,

worldview,

harmony,

Universe.

\begin{abstract}
Understanding of beauty is one of the valid exponents of the individual worldview. And aesthetics ideas express a worldview of the historical and cultural age. Why is the world beautiful? What is the beauty of the Universe, nature, and human proves? Those issues troubled both Ukrainian and British philosophers of the 17-18 centuries. In this article, I outline and compare philosophical views of aesthetics of Vitaliy from Dubno, Kyrylo TranquilionStavrovetsky, Theophan Prokopovych, Heorhiyi Konysky, John Locke, George Berkeley, Francis Hutcheson, and David Hume. The aesthetics ideas of these philosophers are in many common. They regard the Universe and the person in terms of beauty and divinity. Humanistic tendencies of the era expressed in recognition of the perfectness and beauty of the human. On the whole, the ideas of philosophers sound like peculiar Aesthetical Optimism. Because, even ugliness is not excessive, and enhances the beauty and perfection of the Universe.
\end{abstract}

Citation: Viktoriya Havrylenko. (2020) Aesthetic Ideas in Ukrainian and British Philosophy of 17-18th Centuries. International Journal of Innovative Technologies in Social Science. 1(22). doi: 10.31435/rsglobal_ijitss/31012020/6873

Copyright: (C) 2020 Viktoriya Havrylenko. This is an open-access article distributed under the terms of the Creative Commons Attribution License (CC BY). The use, distribution or reproduction in other forums is permitted, provided the original author(s) or licensor are credited and that the original publication in this journal is cited, in accordance with accepted academic practice. No use, distribution or reproduction is permitted which does not comply with these terms.

Introduction. Each historical and cultural period has its aesthetics and understanding of beauty. Those things which people consider as a beautiful show not only personal worldview but also the worldview of the era is. Aesthetic issues troubled the philosophers all the time. The philosophy of the 1718th centuries characterized by reliance on rationality or religion, the desire to understand natural processes, the Universe, the human mind, and will. Aesthetic ideas appear in this time in the context of general tendencies of the era. Philosophers of New Time tried to determine the essence of beauty and its features. Therefore the article aims to highlight the main aesthetics ideas in Ukrainian and British philosophy of the 17-18th centuries. In this research used methods of analysis and comparison.

Aesthetic issues in philosophy of the Enlightenment are reviewed in researches of Beardsley M., Brady E., Carlson A., Carrol N., Cohen T., Costello D., Crawford D., Dickie G., Ivanio I., Kivy P., Levinson J., Nychyk V., Purviance S., Rossiter E., Schellekens E., Schueller H., Shelley J., Tanehisa O., Walmsley J., and others. These scientists investigate aesthetic ideas in philosophy as a whole and particularly in the philosophical works of John Locke, George Berkeley, David Hume, Francis Hutcheson, Theophan Prokopovych. But there is still no complete picture of the basic aesthetic tendencies in Ukrainian philosophy of the 17-18th centuries. That is why the discovering and comparing the aesthetics ideas in Western and Eastern Europe (Great Britain and Ukraine) is actual.

The understanding of beauty in 17-18th-centuries philosophy is closely linked with religion. Its notedly in the work Diopter or the Mirror of Human Living in the World by Vitaliy from Dubno (1612). According to philosopher, perception, and cognition of created beauty guide the man to the cognition of the 
Creator`s beauty. At the same time, visible beauty is just a drop relative to unseen beauty. That unseen beauty is a Kingdom of heaven ${ }^{1}$. Vitaliy from Dubno affirms that pride is always the consequence of beauty. The same idea became a base of the aesthetic theory of Hume in the next century. By Christianity religion, body beauty is fugacious, frail, and destructive. That is why physical beauty is a delusion of mind. So the philosopher is advice to adorn the soul, not the body. Soul's beauty is eternal and immortal. "Any other beauty is in vain, fragile, ephemeral, crazy, and perishable. Time destroys beauty"'2.

Other Philosopher and Theologian of the first half of 17th century Kyrylo TranquilionStavrovetsky underlines beauty of the world. The philosopher is trying to attract attention to the perfection of God's creation. In the work About World and Heaven Creation Tranquilion-Stavrovetsky focuses attention on the beauty of the Universe and its single parts. The philosopher says that God created the world as a first visible beauty ${ }^{3}$. When God separated light for the sun, moon, and the stars, he made the world bright, and visible and beautified it. "And then [God] enlightened all visible under the sky, and beautified existence of the world by its siting"4.

But at the beginning of creation, Earth was black and wet, uncovered, and unadorned. Sun drained it and by God's command appeared herbs, flowers, fruitful seeds, trees. With this action, God beautified the nudity of the Earth. Thus the natural World is beautiful since its creation. The same thought expressed in the ancient Ukrainian carol: Saint Peter gets golden sand from the bottom of the sea. He sows the sand, and from this sand appears stars on the sky and flowers on the ground. This example shows that one of the worldview features of Ukrainians is the perception of the beauty of the Universe.

God's creation (the Earth) is beautiful. God planted the flowers, reached earth fertile seeds and fruits (sweet or bitter), fruitful trees. God enriched Earth with groves and mountains, precious stones, gold, and silver. By these things, God beautified the Earth, which is a house for the human. The separate part of the work Tranquilion-Stavrovetsky dedicated to the beauty of heaven (About Greatness and Beauty of the Heaven). Heaven is an excellent God's work: "God spread out beautiful, wide, and high heaven like common clothes for all visible world"5. God has adorned heaven with different kinds of beauty. Beautiful sun, moon, and stars are like lamps in the big house for humans. Tranquilion-Stavrovetsky interprets the World as a luxury and magnificent palace for the "King of all the light" (human) ${ }^{6}$. Beautiful, luxury, and self-sufficient world God created for the mortal human body. Accordingly, for the immortal human soul, God prepared the invisible beautiful world (paradise).

In work About the Creation of Human Tranquilion-Stavrovetsky underlines that the human soul activates five senses. Herewith humans can percept the beauty and delights of the visible world. The human can cognize even divine secrets and beauty through mental taste. The philosopher considers that perception of the visible beauty refers to the body (or physical) pleasures. Those kinds of beauty expressed in women`s prettiness, exquisite clothes, precious stones, diamonds, gold, and silver, songs, and music.

In a similar way John Locke, in his dispute between atheists, and theists, use beauty, and order of the world as proof for God's existence. The philosopher does not doubt that God keeps things "in that order and beauty" as we see ${ }^{7}$. Senseless material Substance could not give birth to some else, senseless mater. Lock concentrated on the beauty and order of the world things. For the Philosopher, "the argument from design plays in the overall proof for Good existence" ${ }^{8}$. According to Locke, beauty, order, and natural harmony evidence that the matter was not the eternal first cogitative being. But instead: this harmony and beauty of nature can prove that the first eternal being was cogitative spirit ${ }^{9}$. Harmony and beauty of the Universe contradict to the thought about accidental nascence of the world.

\footnotetext{
${ }^{1}$ Vitaliy from Dubno, "Diopter or the Mirror of Human Living in the World," in History of Ukrainian Philosophy, eds. M. Tarasenko and M. Rusyn (Kyiv: Lybid, 1993), 76-87.

2 Ibid., 80.

${ }^{3}$ Kyrylo Tranquilion-Stavrovetsky, "Excerpts from Prose and Verse Philosophical Works," in Sights of Brotherhood Schools in Ukraine. The ending of 17-beginning of 18thcentury, eds. V. Shynkaruk and V. Nichik (Kyiv: Naukova Dumka, 1988), 207-255.

${ }^{4}$ Ibid., 229.

${ }^{5}$ Ibid., 233.

${ }^{6}$ Ibid., 233.

${ }^{7}$ Elliot Rossiter, "Locke Providence and the Limits of Natural Phylosophy," British Journal for the History of Philosophy, no. 22 (2014): 217-235.

${ }^{8}$ Ibid., 223.

${ }^{9}$ Ibid., 233.
} 
Ukrainian philosophers of $17-18^{\text {th }}$ centuries objected accidental nascence of the world too. And for the Ukrainian philosopher of the beginning of the 18th century, Theophan Prokopovych, beauty is a manifestation of divine order. In Natural Philosophy, the philosopher tries to review the contrary category: the ugliness. Procopovych tries to explain appearing of monsters. According to Procopovych, monster or ugliness appear contrary to the intention of nature ${ }^{1}$. Instead: beauty is following the intention of the nature, order, and harmony of nature. But God allows the appearance of the monsters because he wants not to intervene in the creative force of nature ${ }^{2}$. It means that God planed ugliness contrary to nature. But the first of all Creator targeted to beauty. That is why secondary causes that influence things endowed with the desire for the beautiful ${ }^{3}$.

Prokopovych says about perfection and the world beauty of the things. In part about Aristotle`s doctrine of a move, infinity, and continuity, the philosopher affirms that the natural state of rest is positive. By that, Procopovych meant the rest of the movable object. The rest relative to the location is related to the beauty of the object. Aesthetics of the movable object is in its natural rest. The movable object in the rest is in good condition. In that condition object, the best of all keeps "the beauty of all the world" ". That is why the more perfect is the rest than the move. When Prokopovych considers World as a whole, he underlines the a priori beauty of the Universe. The Universe is beautiful. After all, the Greek or Roman word denoting the "world" contained the meaning of beauty and order: "The Greeks called it Cosmos and Romans called it Mundus. Because of either Cosmos in Greeks or Mundus in Romans meant beauty, grace, and order"s.

Prokopovych (as Locke) opposes epicureans, and ideas of the accidental emergence of the world, which proposed in the Ancient philosophy the Epicurus, Democritus or Straton. Prokopovych was a theologian. That is why he aimed to prove the existence of the creative cause and first mover of the world. One of the power proof for the existence of creative force is the aesthetics and beauty of the Universe. This proof Prokopovych considers as most visible. After all, the beauty, greatness, diversity, and structure of the world are the manifestation of God`s wisdom. Such God`s wisdom expressed in a natural connection of all things that go to the same goal. That is the beauty of the Universe is in harmony, regularity, connections of things, and order. All of this is visible evidence of God`s existence.

In philosophical reflections regarding the creation of the world, Prokopovych appeals to aesthetic ideas again. Thus the philosopher thinks that God created the world in spring. Because spring is life-giving, and it is a beautiful season. For Prokopovych, a human is a perfect creation, cause it is God`s masterpiece. And the beauty of the human is in godlikeness. Human is beautiful microcosm because he copies "all of the parts of the divine substance". Beautiful and richness world created as a home for the human. "World is like a much beautiful palace adorned by decorations, clothes, and different reaches"'. That is why God created the human at the end of the creation of the world. God created the world firstly and prepared it to settle a human. Prokopovych's philosophy tells not only about the relevance and comfort of the world but also about its beauty. That is, God not only created a house for the human but decorated it. In this way, the Creator expressed his aesthetic taste through the beauty of the Universe. The part of the Universe aesthetics is the sky. Prokopovych describes the sky through aesthetic perception: it is large, diverse, beautiful, and amazing ${ }^{8}$. Similarly, other creations are both useful and beautiful. For example, mountains are not only useful but make a beautiful landscape ${ }^{9}$.

Prokopovych reviews the influence of beauty on the person. Of course, he said about personal beauty. Thus the physical beauty (as a strength and health) is a gift of nature. The handsomeness of the person is one of the conditions of love appearing. According to Prokopovych, such beauty can attract many friends to a person. Instead, the ugliness can extinguish love. "Because the beauty is a cause of love and the ugliness prevents love"10. For Prokopovych, the beauty of the natural and person`s body

\footnotetext{
${ }^{1}$ Theophan Procopovych, Philosophical Works in Three Books. Book II: Natural Philosophy, Ethics (Kyiv: Naukova Dumka, 1980), 183.

${ }^{2}$ Ibid., 183.

${ }^{3}$ Ibid., 183.

${ }^{4}$ Ibid.,200.

5 Ibid., 284.

${ }^{6}$ Ibid.,310.

${ }^{7}$ Ibid., 310 .

8 Ibid., 320 .

${ }^{9}$ Ibid.,371.

10 Theophan Procopovych, Philosophical Works in Three Books. Book I: Rhetoric (Kyiv: Naukova Dumka, 1979), 300.
} 
is in the harmonious combination of different parts. The person who is characterized by the harmony of the body and the soul is beautiful. "Prokopovych reviews personal beauty as naturalness". . Natural beauty Prokopovych sees in pleasing complexion face and the proper combination of body parts.

Heorhiy Konysky, in his academic course of Natural Philosophy, expresses the same thoughts and ideas as Prokopovych does. The Universe is God's creation, and that is why the World is beautiful. Human is a perfect creation because every person consists of corporeal and incorporeal nature. Moreover, the human is an image of a God-Creator. Konysky regards the ugliness inside the aesthetics tendencies of the era. According to the philosopher, ugliness or monsters emphasize the perfect beauty of other natural things ${ }^{2}$.

Aesthetics ideas of the British philosopher of the beginning of 18th century George Berkeley largely coincide with the ideas of Ukrainian philosophers. For Berkeley, the meditation about the beauty and the order of nature is a noble aim. That is why contemplation of the world's beauty and order is the way to the enlightenment of the spirit ${ }^{3}$. For Berkeley, beauty is constant order, the connection of things, and greatness of nature. Beauty is in the harmony of the Universe. Big things are beautiful through the perfectness and small things through elegance ${ }^{4}$. A required component of the Universe is an imperfection. Imperfect things tint a beauty and show off a perfection of nature ${ }^{5}$. God created a harmonious and aesthetic world. Berkeley expressed his views in detail in work Three Dialogues between Hylas and Philonus. According to Berkeley, beauty not only satisfies aesthetic needs. Beauty is useful as truth if it is considered carefully: "Truth and beauty have this in common: they both show to advantage when looked at closely and carefully"6.

Berkeley follows the tendency of the New Time philosophy. And he considers the perfectness and beauty of nature: "It is such a sincere pleasure to see earth`s natural beauties" (c. 28). For Berkeley, beauty is in different elements of the visible world: in the mountains, forests, oceans, deserts, or season changes. The parts of the Universe are animals and plants. And they are beautiful too. The beauty of every creation is in its organically composed body. But as Berkeley thinks, the origin of beauty is not only physical corpus but the functions of all things. "How finely all things are suited to their particular ends and also to their roles as appropriate parts of the whole"7.

Aesthetic of the Universe is in the earth and heaven. Earthen nature and heaven nature is beautiful because it created by unseen Author. Berkeley describes the aesthetic of heaven`s sphere artistic and rapturously: "How vivid and radiant is the shine of the fixed stars! How magnificent and rich the careless, profusion with which they seem to be scattered throughout the whole vault of the sky!"». For Berkeley (as for Lock, Prokopovych, and Konysky), simultaneous beauty and usefulness of the parts of Creation argue that Universe is the workmanship of $\mathrm{God}^{9}$. Berkeley reviews beauty in the aspect of personal perception. Thus natural beauty can "inspire the soul with secret raptures" ${ }^{10}$. For the person-observer who behold the world's aesthetics, the beauty is in the purple night sky, wild but sweet singing of the birds, a bloom of the trees and flowers.

Francis Hutcheson in Treatise I An Inquiry Concerning Beauty defines beauty as "vast Uniformity amidst an almost infinite Variet"11. That is why the beauty of the world for Hutcheson is in the diversity of colors, a game of lights and shadows, different surfaces (as mountains, hills, and plains), and in animals. Hutcheson divides beauty into two categories: Original or Comparative; Absolute or Relative. According to the philosopher, absolute beautiful are natural creations, artificial forms, figures, and theorems. Absolutely beauty means "only that Beauty which we perceive in

\footnotetext{
${ }^{1}$ Ivan Ivanio, Aesthetics Views of Theophan Prokopovych (Kyiv, 1980), http://litopys.org.ua/procop/proc104.htm.

${ }^{2}$ Heorhiy Konysky, Philosophical Works in Two Books. Book II (Kyiv: Naukova Dumka, 1990), 248.

${ }^{3}$ George Berkeley, A Treatise Concerning the Principles of Human Knowledge, (Edited by David R. Wilkins, 2002), 40, https://www.maths.tcd.ie/ dwilkins/Berkeley/HumanKnowledge/1734/HumKno.pdf.

${ }^{4}$ Ibid., 41.

5 Ibid., 53.

${ }^{6}$ George Berkeley, Three Dialogues between Hylas and Philonus (Copyright by Jonathan Bennett, 2017), 27, https://www.earlymoderntexts.com/assets/pdfs/berkeley1713.pdf.

${ }^{7}$ Ibid., 28.

${ }^{8}$ Ibid., 29.

${ }^{9}$ Ibid., 30.

${ }^{10}$ Ibid., 1.

${ }^{11}$ Francis Hutcheson, An Inquiry into the Original of Our Ideas of Beauty and Virtue: in Two Treatises (Indianapolis: Liberty Fund, 2004), 30.
} 
Objects without comparison to anything external"1. Instead, the objects which exist as mimicry or imitation classifies by Hutcheson as Comparative beauty. "Comparative or Relative Beauty is that which we perceive in Object, commonly considered as Imitations or Resemblances of something els"2. It seems the philosopher means artworks. But Hutcheson underlines that peculiar absolute beauty contained in musical harmony. Hutcheson thinks that musical harmony or beauty of sounding is not percepts as an imitation of something else ${ }^{3}$. Susan Purviance rightly generalizes aesthetics ideas of Hutcheson as "Aesthetic Realism"4.

David Hume examines beauty and ugliness in the context of human passions. According to Hume, beauty necessarily leads the person to the proudness (such thought we found in works of Vitaliy from Dubno). Instead, ugliness leads the person to humility. On another side, beauty causes pleasure, and ugliness causes displeasure: "Beauty gives us a special delight and satisfaction - and ugliness special unpleasure - no matter what kind of beauty or ugliness it is" ${ }^{\text {" }}$. Hutcheson defines beauty in terms of its impact on humans. As the philosopher says, "For something to be beautiful is for it to be put together in such a way as to give pleasure and satisfaction of our nature or by custom or by caprice" . Pleasure is the essence of beauty. That is why pleasure is undivided from beauty. "Beauty is just a form that produced pleasure"

For Hume, the source of proudness is both natural (physical) and moral beauty. According to the philosopher, personal beauty means physical health and cheerfulness that express in activity and strength. Beauty and ugliness in actions, artworks, or other objects evoke calm or violent feelings. Beauty which, leads to proudness is always appertaining to the person: "No-one is ever proud of beauty, considered in the abstract" $"$. That's why personal beauty gives the man both pleasure and proudness. And personal ugliness leads the person to displeasure and humility. At the same time, some things do not apply to the person but look pleasantly. For example, watching beautiful fish in the ocean may evoke pleasure but not evoke a proudness. Hume (as a Prokopovych) thinks that beauty is a condition of love appearing. But Prokopovych says about the public's favor for the orator, and Hume implies a love between sexes.

At work $O f$ the Standard of Taste, Hume tries to explain the essence of beauty through the person's perception of beauty. The philosopher proposes an idea of the subjectivity of beauty. He says: "Beauty is no quality in things themselves: It exists merely in the mind which contemplates them; and each mind perceives a different beauty" . It means that beauty depends on the taste of the person who percept it. Elisabeth Schellekens underlines that the aesthetical standard of Hume is empirical because it based on experience and feelings ${ }^{10}$. At the same time, Hume proposes an idea of the existence of Real Beauty and Real Deformity. Defects of the sense organs of the person may impact on the perception of beauty. Such thought of Hume is accordant to the Hutcheson's idea of absolute or relative beauty. In whole both Hutchenson and Hume admitted the existence of principles of beauty, "They maintained that although judgments of beauty are judgments of taste and not of reason"

Herbert Schueller says about the 18th century: "Beauty is social, it was thought both the place of beauty and that a society having the characteristic called harmony"12. Generalization of the aesthetics ideas of Ukrainian and British philosophers of the 17-18th centuries showed that the understanding of beauty had

\footnotetext{
${ }^{1}$ Ibid., 27.

${ }^{2}$ Ibid., 27.

${ }^{3}$ Ibid., 34.

${ }^{4}$ Susan Purviance, "Hutcheson`s Aesthetic Realism and Moral Qualities," History of Intellectual Culture, vol. 6 , no. 1 (2006): 5.

${ }^{5}$ David Hume, Treatise of Human Nature. Book II: The Passions (Copyright by Jonathan Bennett, 2017), 161, https://www.earlymoderntexts.com/assets/pdfs/hume1739book2.pdf.

${ }^{6}$ Ibid., 162.

7 Ibid., 162.

${ }^{8}$ Ibid., 150 .

9 David Hume, "Of the Standard of Taste" In English Essays from Sir Philip Sidney to Macaulay, ed. C. W. Eliott (P. F. Collier \&Son, 1910), 218.

${ }^{10}$ Anna Elisabeth Schellekens, "A Reasonable Objectivism for Aesthetic Judgements: Towards an Aesthetic Psychology" (PhD diss., University of London, 2008), 111, https://core.ac.uk/download/pdf/73478.pdf.

${ }_{11}$ James Shelley, "The Concept of the Aesthetic," in The Stanford Encyclopedia of Philosophy, ed. Edward N. Zalta (2017), https://plato.stanford.edu/archives/win2017/entries/aesthetic-concept/

${ }^{12}$ Herbert M. Schueller, "Correspondences between Music and the Sister Arts, According to 18th Century Aesthetic Theory," The Journal of Aesthetics and Art Criticism, vol. 11, no. 4 (1953): 335.
} 
two lines. The first line considers beauty as evidence of God`s creation of the world. And the visible beauty of the earth, heaven, and human, which obeys to order, and harmony proves that. Individual objects and the Universe in whole consider as beautiful. In the creation of the world expressed an aesthetic taste of the Creator. That is, God primarily made uncovered earth, and then, he adorned it as a home for the human. Accordingly, the visible beauty of the nature and world in whole exists for the enjoyment of the aesthetics senses of humans. Beautiful (both in the man and nature) are those things which obey divine order and harmony. A priory beautiful in the human is the godlikeness. The world beauty is in diversity and variability of the forms that linked through mutual harmony.

The second aesthetics line understands the beauty in terms of perception by person and impact on a person. Thus beautiful inspire to exalted feelings, evoke love, proudness, and humility. The person percept beauty through his senses and aesthetics taste. Through the external senses, the person can grasp the visible beauty of nature and the world. And using the mental taste, the person can grasp the beauty of unvisible yet paradise. Therefore, the aesthetics ideas of the British and Ukrainian philosophers of 17-18th centuries developed under the impact of the concept of creationism. That is why ideas of the philosophers based on admiring the perfection and aesthetics of the visible world. But British philosophers tried to define and classified beauty. At the same time Ukrainian philosophers tried to describe beauty. Humanistic tendencies of the era expressed in recognition of the perfectness and beauty of the human. It is for the human God created a wonderful and beautiful world. Both British and Ukrainian philosophers presented such an idea. On the whole, the ideas of philosophers sound like peculiar Aesthetical Optimism. After all, even ugliness is not excessive in perfect Universe because it enhances the beauty and perfection of the visible world.

\section{REFERENCES}

1. Berkeley, George. A Treatise Concerning the Principles of Human Knowledge. Edited by David R. Wilkins, 2002. https://www.maths.tcd.ie/ dwilkins/Berkeley/HumanKnowledge/1734/ HumKno.pdf.

2. Berkeley, George. Three Dialogues between Hylas and Philonus. Copyright by Jonathan Bennett, 2017. https://www.earlymoderntexts.com/assets/pdfs/berkeley 1713.pdf.

3. Hume, David. “Of the Standard of Taste." In English Essays from Sir Philip Sidney to Macaulay, edited by C. W. Eliott, 215-236. P. F. Collier \&Son, 1910.

4. Hume, David. Tratise of Human Nature. Book II: The Passions. Copyright by Jonathan Bennett, 2017. https://www.earlymoderntexts.com/assets/pdfs/hume1739book2.pdf.

5. Hutcheson, Francis. An Inquiry into the Original of Our Ideas of Beauty and Virtue: in Two Treatises. Indianapolis: Liberty Fund, 2004.

6. Ivanio, Ivan. Aesthetics Views of Theophan Prokopovych. Kyiv, 1980. http://litopys.org.ua/procop/proc104.htm.

7. Konysky, Heorhiy. Philosophical Works in Two Books. Book II. Kyiv: Naukova Dumka, 1990.

8. Procopovych, Theophan. Philosophical Works in Three Books. Book I: Rhetoric. Kyiv: Naukova Dumka, 1979.

9. Procopovych, Theophan. Philosophical Works in Three Books. Book II: Natural Philosophy, Ethics. Kyiv: Naukova Dumka, 1980.

10. Purviance, Susan. "Hutcheson`s Aesthetic Realism and Moral Qualities." History of Intellectual Culture, vol. 6, no. 1 (2006): 1-14.

11. Rossiter, Elliot. "Locke Providence and the Limits of Natural Phylosophy." British Journal for the History of Philosophy, no. 22 (2014): 217-235.

12. Schellekens, Anna Elisabeth. "A Reasonable Objectivism for Aesthetic Judgements: Towards an Aesthetic Psychology.” PhD diss., University of London, 2008. https://core.ac.uk/download/pdf/73478.pdf.

13. Schueller, Herbert. "Correspondences between Music and the Sister Arts, According to 18th Century Aesthetic Theory," The Journal of Aesthetics and Art Criticism, vol. 11, no. 4 (1953): 334-359.

14. Shelley, James. "The Concept of the Aesthetic." In The Stanford Encyclopedia of Philosophy, edited by Edward N. Zalta. 2017. https://plato.stanford.edu/archives/win2017/entries/aesthetic-concept/

15. Tranquilion-Stavrovetsky, Kyrylo. "Excerpts from Prose and Verse Philosophical Works." In Sights of Brotherhood Schools in Ukraine. The ending of 17-beginning of 18th century, edited by V. Shynkaruk and V. Nichik, 207-255. Kyiv: Naukova Dumka, 1988.

16. Vitaliy from Dubno. "Diopter or the Mirror of Human Living in the World." In History of Ukrainian Philosophy, edited by M. Tarasenko and M. Rusyn, 76-87. Kyiv: Lybid, 1993. 